\title{
SENSORY PROFILE OF 3 IN 1 INSTANT COFFEE USING EMOTIONAL-SENSORY MAPPING, FLASH PROFILE, AND CATA (CHECK-ALL-THAT-APPLY) METHODS
}

\author{
[Profil Sensori Kopi Instan 3 in 1 dengan Metode Emotional-Sensory Mapping, Flash \\ Profile, dan Cata (Check-All-That-Apply)]
}

\author{
Dase Hunaefi ${ }^{1,2) \star}$ dan Wicensky Marusiva ${ }^{1)}$ \\ 1) Departemen IImu dan Teknologi Pangan, Fakultas Teknologi Pertanian, IPB University, Bogor \\ ${ }^{2)}$ South East Asian Food and Agricultural Science and Technology (SEAFAST) Center, IPB University, Bogor
}

Received January $28^{\text {th }} 2021 /$ Accepted December $1^{\text {st }} 2021$

\begin{abstract}
Three in one instant coffee is popular among university students. A variety brands of such instant coffee are available on the market. However, the literature on the sensory aspects of the instant coffee is rather limited slim. The project aimed to test three-in-one instant coffee sachets for their sensory characteristics. Two methods, CATA (Attributes and Emotional Mapping) and Flash Profile (extension of Free Choice Profiling) were employed to generate the attribute profiles and emotional dashboard. Sixty IPB University students were selected as panelists. Sensory attributes terminologies and their relation to emotion were generated using Focus Group Discussion among instant coffee heavy drinker. Profile of coffee $\mathrm{D}$ showed a creamy texture, while sweetness and milky was dominant when it came to coffee $B$ and coffee $C$. The creaminess in coffee $G$ was strongly related to feelings of happiness in a consumer. In addition, the sweet and milky taste and flavor in coffee B was seen as a relaxing and luxurious feeling. A Preference Mapping was constructed, and it showed that sweetness, milky, and creaminess improved the liking of the student consumers that make coffee $\mathrm{C}$ the most preferred brand among the panelists. In short, the use of flash profiles and check-all-it-dilute/CATA (attributes and emotional) equipped with preference mapping can provide emotional attributes and dashboards that will be important to understand products more than just consumer liking.
\end{abstract}

Keywords: CATA, emotional sensory mapping, flash profilling, instant coffee, sensory profiling

\begin{abstract}
ABSTRAK
Kopi instan 3 in 1 sangat digemari oleh kalangan mahasiswa. Terdapat beragam merek kopi instan 3 in 1. Informasi mengenai karakteristik sensori kopi instan relatif sedikit. Penelitian ini bertujuan untuk mengevaluasi karakteristik sensori pada produk kopi instan 3 in 1 dalam kemasan sachet. Dua metode, Check-All-That-Apply/CATA (Atribut dan Pemetaan Emosional) dan Flash Profile (yang disatukan dengan Free Choice Profiling) digunakan untuk menghasilkan profil atribut dan konsep emosional yang terikut. Enam puluh mahasiswa IPB University terpilih melalui skrining sebagai panelis. Terminologi atribut sensori dan keterkaitan emosional dihasilkan dengan menggunakan Focus Group Discussion konsumen berat kopi instan. Profil kopi $D$ menunjukkan tekstur yang lembut, sedangkan rasa manis dan susu mendominasi kopi $B$ dan kopi C. Tekstur creamy dalam kopi $D$ sangat terkait dengan perasaan bahagia seorang konsumen. Selain itu, rasa manis dan susu pada Kopi B dipandang sebagai perasaan yang menenangkan dan mewah. Preference Mapping yang dibangun menunjukkan bahwa rasa manis, rasa susu, dan creamy mouthfeel meningkatkan kesukaan konsumen mahasiswa yang menjadikan kopi $C$ sebagai merek yang paling disukai di kalangan mahasiswa IPB University. Melalui flash profile dan CATA (Attributes and Emotional) yang dilengkapi dengan pemetaan preferensi memberikan atribut dan peta emosi yang akan menjadi penting untuk memahami produk lebih dalam dari sekedar keinginan konsumen.
\end{abstract}

Kata kunci: CATA, emotional sensory mapping, flash profilling, kopi instan, sensory profiling

*Corresponding Author: E-mail: dashcbdk@apps.ipb.ac.id 


\section{INTRODUCTION}

Coffee is one of the most recognized drinks in the world besides tea and chocolate (Zanin et al., 2021; Ribeiro et al., 2021). Based on data from the International Coffee Organization (ICO, 2021), the level of world coffee consumption in 2020 reached 171.9 million bags million bags per $60 \mathrm{~kg}$ of coffee packs and an annual average increase of $6.1 \%$ since 2019. Several countries in Europe, such as Finland, have consumed coffee reaching $9.60 \mathrm{~kg}$ per capita or 2.64 cups per day (Bemfeito et al., 2021). In Indonesia, coffee consumption in the last year has increased by $60 \%$ from $2010-2019$, with a total domestic consumption of 4.08 millions of $60 \mathrm{~kg}$ bags, with export volume of 4.5 millions of $60 \mathrm{~kg}$ bags resulted in $4^{\text {th }}$ position in the world, while the total volume coffee produced was 761000 metric tons (Hirschmann, 2020; Hirschmann, 2021).

Two types of processed coffee are widely available on the market, namely ground coffee and instant coffee (Yusianto and Nugroho, 2014). The difference between these two types of processed coffee is that ground coffee is a pure coffee powder that is directly brewed with boiling water, has a coarser texture, contains more pulp, has a more pungent coffee aroma, has higher side effects and a level of thickness that can be adjusted accordingly-the tongue of the connoisseur. Meanwhile, instant coffee is coffee that is ready to serve by the rehidration. Instant coffee has a fragrant aroma, does not contain much waste, and has various flavors (Gao et al., 2021). The habits or lifestyles of today's society that tend to be practical have led to increased consumption of instant coffee (Huang et al., 2021).

Emotion is one of the critical factors that consumers consider when making product purchase decisions (de Melo et al., 2021; Nasermoadeli et al., 2012). Positivity in emotions can add value to a product, whereas negativity can subtract value. External factors like advertising and packaging can influence consumer emotions while internal factors like the sensory profile of a product have an impact on it (Jaeger et al., 2019). Consumers will make a relationship between the sensory attributes of a product (taste, aroma, mouthfeel, aftertaste, and flavor) with the internal experience/emotions experienced when tasting the product (feeling comfortable and relaxed) (Huseynov et al., 2021; Nezlek et al., 2021).

The description of the product's sensory characteristics has become an integral part of food and beverage companies (Valentin et al., 2012). Information obtained from descriptions of product sensory characteristics enables companies to make more precise business decisions, become a reference in developing ideal products according to consumers, know the effects of changes in formulas and processes, and are also useful for quality control purposes (Varela and Ares, 2012). Descriptive tests are used to identify important sensory characteristics in a product and provide information about these characteristics intensity (Pramudya et al., 2021). However, using descriptive methods to evaluate the sensory characteristics necessitates panelists who have been trained to do so. Developing the trained panelists normally takes a lot of time and effort. Luckily, current development methods for the test, such as the Flash Profile Method and Check-All-That-Apply (CATA) (Veríssimo et al., 2020; Belusso et al., 2016), are not contingent on having trained panelists.

Based on research, according to Rabelo et al. (2021), the flash profile method is an accurate method for sensory mapping and can also provide relevant results. Also, the flash profile method is a method that can be used to obtain product profiling when trained panelists are not available quickly.

The industry's pressure to develop alternative methods that eliminate the need and the cost for panelist training and collect sensory information directly from consumers has made several consumer profiling methods developed rapidly in the last decade (Berget et al., 2020). One of those methods is CATA. The Check-All-That-Apply (CATA) method is a simple and fast method of gathering information about a product based on consumer perceptions (McCain-Keefer et al., 2020). Besides, this method is very appropriate for naive consumers who can see how consumers understand the product from a sensory perspective and how sensory characteristics can compose consumers' perception patterns (McCain-Keefer et al., 2020).

Sensory evaluation in the food industry is an important thing to do. Determination of consumer selection of an instant coffee product is based on consumers' emotions when tasting an instant coffee product, and these emotions are influenced by the sensory profile contained in instant coffee products. This study aimed to determine the sensory profile of instant coffee using consumer panelists with emotional-sensory mapping, flash profile, and Check-AllThat-Apply (CATA) methods. This study's results were expected to obtain information about instant coffee products' sensory profile that can be used for new product development using emotional-sensory mapping, flash profile, and CATA methods using consumer panelists.

\section{MATERIALS AND METHODS}

\section{Materials}

The main samples used in this research are three-in-one (coffee, non-dairy creamer, and sugar)instant coffee products packed in sachet. Eight coffee products are 1) Coffee A, 2) Coffee B, 3) Co- 
ffee C, 4) Coffee D, 5) Coffee E, 6) Coffee F, 7) Coffee $\mathrm{G}$, and 8) Coffee $\mathrm{H}$. Other materials used are mineral water and crackers. The tools used in this study were cups, trays, spoons, labels, paper, stationery, and questionnaire paper. The sensory analysis was performed using Emotional-Sensory Mapping, Flash Profile, and check-all-that-apply (CATA) methods in the sensory laboratory Department of Food Science and Technology, IPB University.

\section{Methods}

The research was conducted in four stages: the first stage involved panelist screening, the second stage involved Focus Group Discussions (FGDs), the third stage involved sensory evaluations of eight 3 in 1 instant coffees using the flash profile method, emotional-sensory mapping, and check-all-thatapply (CATA) with consumer panelists, and the fourth stage involved data processing using XLSTAT. In order to satisfy the applicant's interest in Good Sensory Practices, along with safety concerns, the general guideline on ISO 11136 (https: //www.iso.org/standard/73557.html) was followed.

\section{Sample preparation and presentation}

Sample in the form of instant coffee 3 in 1 dissolved in hot water at $80^{\circ} \mathrm{C}$ according to the packaging's serving instructions. All samples were then presented at the same temperature to avoid bias. The sample was presented as $80 \mathrm{~mL}$ in a small glass measuring $100 \mathrm{~mL}$, given a random three-digit number code. Mineral water and crackers were given to the panelists as neutralizers to neutralize the taste buds at each sample change.

Testing of 3 in 1 instant coffee profiles using the flash profile method (free elicitation) (Manstan et al., 2020)

The free choice profiling methods were conducted in conjunction with the Flash Profile methods (FCP). This method uses 30 panelists, who are coffee consumers after the first stage of screening. Each sample of 3 in 1 instant coffee was served as much as $80 \mathrm{~mL}$ with mineral water and cracker as a neutralizer. The panelist tested the sample and wrote down the sensory attributes he/she thought were present, without any guidance or being guided by the panel leader regarding the attributes that should be assessed. After the panelists wrote the list of attributes, the panelists were asked to rank each attribute's intensity from the entire sample (Manstan et al., 2020).

Testing of 3 in 1 instant coffee profiles using the emotional-sensory mapping method (Mané et al., 2021)

This test method used 30 panelists who are coffee consumers. Each sample of 3 in 1 instant coffee was served as much as $80 \mathrm{~mL}$ in $100 \mathrm{~mL}$ cup with mineral water and cracker as a neutralizer. Panelists were asked to taste the sample and rate their emotions when tasting the sample (Mané et al., 2021).

3 in 1 instant coffee profile testing using the check-all-that-apply (CATA) method follow by the preference mapping (Lobo et al., 2021)

In the Check-All-That-Apply (CATA) test method, there is a selection of ideal perception profiling in consumers' mind. The panelists used were 30 consumers. In the beginning, the panelists were asked to fill in the attribute column for the ideal coffee before tasting the sample. The panelist then tasted the sample and assessed what sensory attributes were felt in the sample by marking the sensory attributes that he/she thinks can describe the sample (Lobo et al., 2021). Panelists were also asked to rate the intensity of liking for the coffee samples with a 6 hedonic scale (very dislike to very much like). The preference mapping was generated based on the frequencies of the liking (Lobo et al., 2021).

Flash profile data analysis (Reinbach et al., 2014)

The flash profile method's data processing was performed using XLSTAT covering Generalized Procurement Analysis (GPA) tools. The result of this GPA tool was in the form of product configuration consensus to show how the product is assessed or perceived by each panelist (Montanuci et al., 2015). One of the resulting data analyses was PCA, which was compared with other methods, namely CATA (Reinbach et al., 2014).

\section{Emotional-sensory mapping data analysis with Check-All-That-Apply (CATA) (Grasso et al., 2016)}

Emotional-sensory Mapping method data analysis was performed using XLSTAT covering CATA analysis tools. The resulting data analysis was in Cochran's $Q$ test, correspondence analysis, Principal Coordinate Analysis (PCoA), and penalty analysis. Cochran's $Q$ test was used to identify significant differences between samples in each of the CATA test attributes (Ares et al., 2014). If the pvalue was $<0.05$, there was a significant difference between samples, whereas if the $P$-value is $>0.05$, there was no significant difference between samples (Grasso et al., 2016).

Correspondence analysis (CA) was used to obtain a two-dimensional representation of the sample and the relationship between attributes and samples in the CATA test. This analysis was commonly used to visualize frequency tables, where rows represent samples and columns represent attributes. The ideal product was added as a complement to the analysis (Ares et al., 2014). 
Principal Coordinates Analysis (PCoA) was applied to visualize the correlation between coefficients and results on a two-dimensional map (Meyners et al., 2013). In this case, the data displayed was the sensory profile, emotional attributes, and favorite data in dots.

Penalty analysis was carried out based on a comparison of consumer perceptions between the sample and the ideal product and its effect on preference value. Based on the penalty analysis results on XLSTAT, the samples' sensory attributes were grouped into 5 categories: must-have, nice to have, must not have, do not influence, and do not harm.

\section{RESULTS AND DISCUSSION}

\section{Panelists' profile}

The total panelists for the flash profile test, CATA, and Emotional Sensory Mapping were 60 students from IPB University who are 3 in 1 instant coffee consumers with a male to female ratio of 30 to $70 \%$. The total panelists used in the flash profile test, CATA, and Emotional Sensory Mapping used 60 panelists selected from the IPB University students who are the 3 in 1 instant coffee consumers with a ratio of $30 \%$ male and $70 \%$ female. The panelists included 30 participants for the flash profile (as an extension of free choice profiling) and 30 participants for the emotional sensory mapping and CATA. The panelists' ages ranged from 19 to 22 years. The frequency of panelist coffee consumption can be seen in Figure 1.

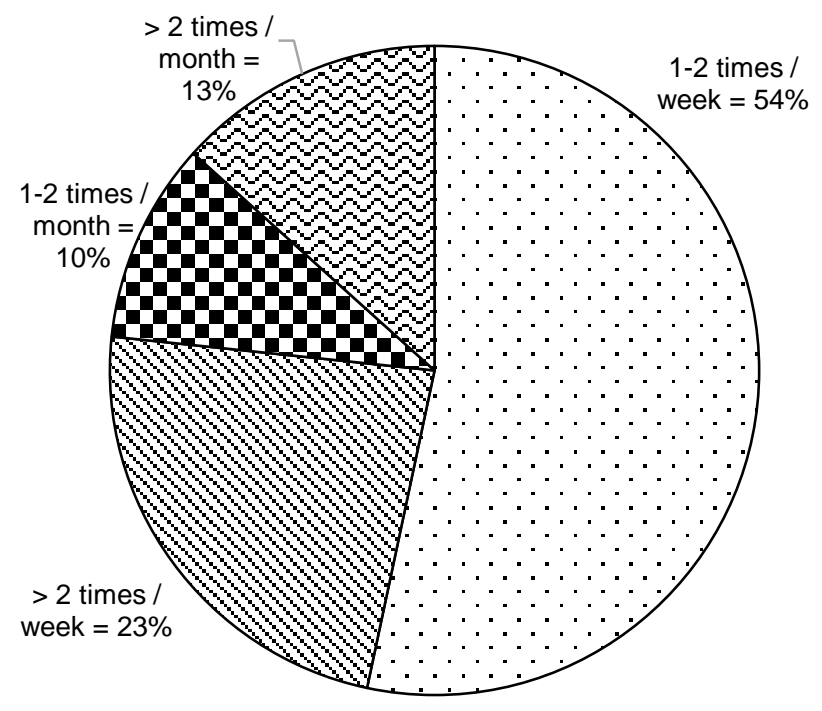

Figure 1. Frequency of panelist coffee consumption

\section{Focus group discussion (FGD)}

This Focus Group Discussion (FGD) was conducted to ascertain the sensory and emotional attributes associated with 3 in 1 instant coffee products used in the CATA and Emotional Sensory Mapping methods. There were 27 sensory attributes to describe chracteristics of coffee and their descriptions were provided to the panelists. Table 1 summarizes the results of the FGD.

The discussion results obtained 10 emotional attributes, namely happy, nostalgic, calm, satisfied, luxurious, bored, energetic, flat, anxious, and safe. There were 15 sensory attributes divided into 4 categories, namely aroma, taste, aftertaste, and mouthfeel. The sensory attributes for aroma were roasted, caramel, smokey, and burnt. Taste attributes were milky, bitter, sweet, and sour. Aftertaste attributes were sour, bitter, dry, and sweet, while mouthfeel/ texture attributes were creamy, viscosity, and watery.

\section{3 in 1 instant coffee sensory profile with flash profile method}

Testing the sensory profile of instant coffee 3 in 1 with the flash profile method using 30 panelists obtained a total of 8 dominant sensory attributes. Acquired sensory attributes include milky, sweet, bitter, caramel, nutty, coffee, sour, and creamy. The test results were processed using the GPA tools on XLSTAT to produce a Procrustes Analysis of Variance (PANOVA) table, which can be seen in Table 2.

The PANOVA table serves to determine which sources of variation have a significant impact on overall consensus resolution. This table summarizes each GPA transformation's efficiency in terms of reducing total variability (Keskin et al., 2012; Labbe et al., 2021). Table 2 shows that translation was the most efficient transformation and significantly reduces the deviation or deviation between the panelists' results because it had the smallest $P$-value.

Another result obtained from the GPA tools is a PCA curve, which showed the correlation between the eight dominant attributes and the 3 in 1 instant coffee sample. The first quadrant was the $\mathrm{E}$ sample with sensory characteristics of bitter, coffee, sour, and nutty. The second quadrant contained samples of coffee $F$, coffee $H$, and coffee $G$, which had creamy sensory characteristics. The third quadrant contained coffee $A$ and coffee $G$ with caramel sensory characteristics. The fourth quadrant contained coffee $\mathrm{C}$ and coffee $\mathrm{B}$ with milky and sweet sensory characteristics. The correlation between sensory attributes and samples were tested by the flash profile method can be seen in Figure 2. 
Table 1. Summary of focus group discussion

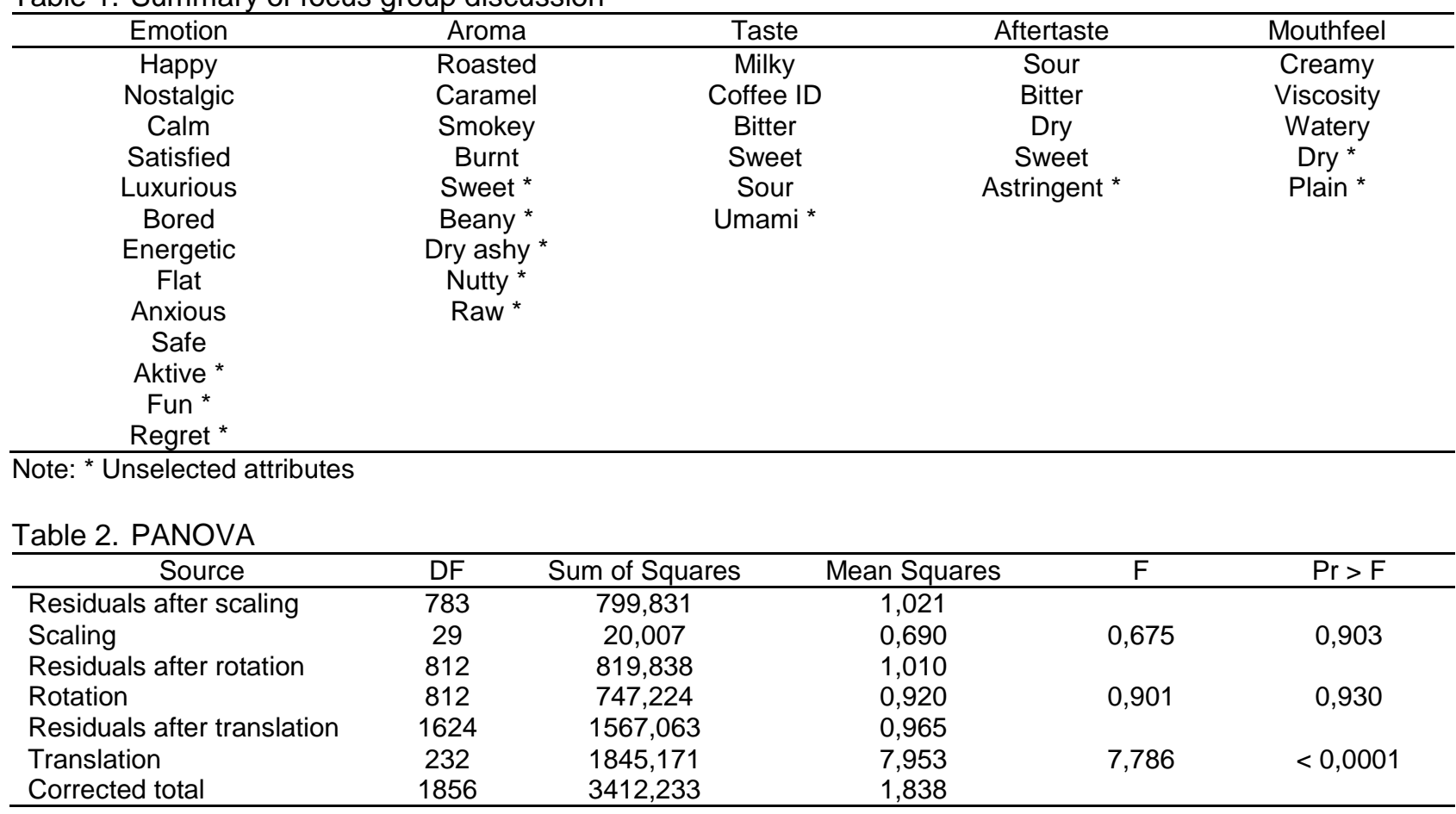

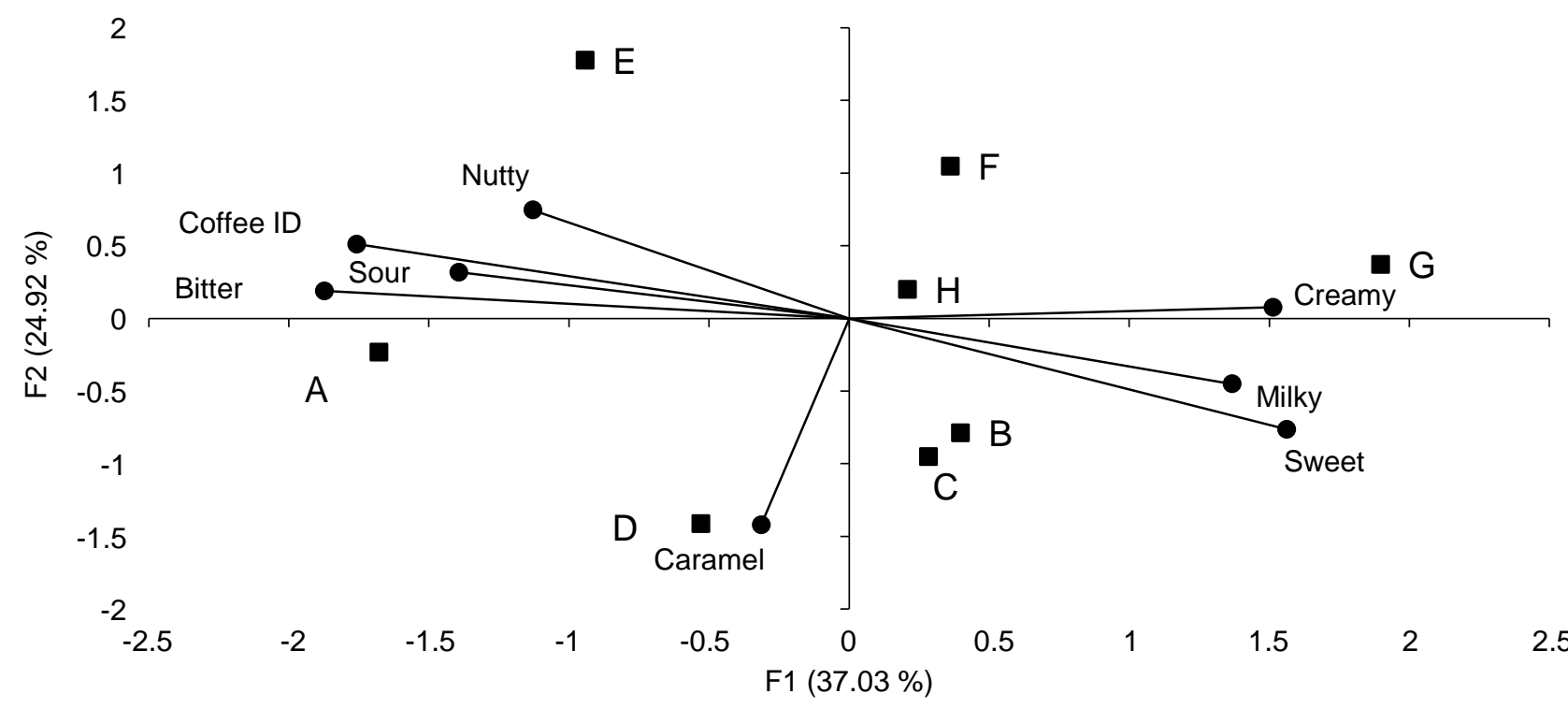

Figure 2. PCA curve of the flash profile method of commercial 3 in 1 coffees used generilized procrustes analysis

3 in 1 instant coffee sensory profile with CATA method

The Cochran's $Q$ test analysis of McNemar's multiple pairwise comparisons compared each of the sensory attributes in each sample with a significance level of $5 \%$. The results of the Cochran's $Q$ test showed that all sensory attributes were significantly different in each sample at a significance level of $5 \%$, except for sour taste $(P=0.055)$, dry aftertaste
( $P=0.312)$, viscous $(P=0.270)$ and mouthfeel watery $(P=0.844)$. The correspondence analysis results were that a biplot map was obtained that represents the profile of 3 in 1 instant coffee and ideal coffee according to the appropriate sensory attributes (Ares et al., 2014; Fujimoto et al., 2021). A biplot map depicting the correlation between the sample, the ideal coffee product, and the sensory attributes can be seen in Figure 3 . 


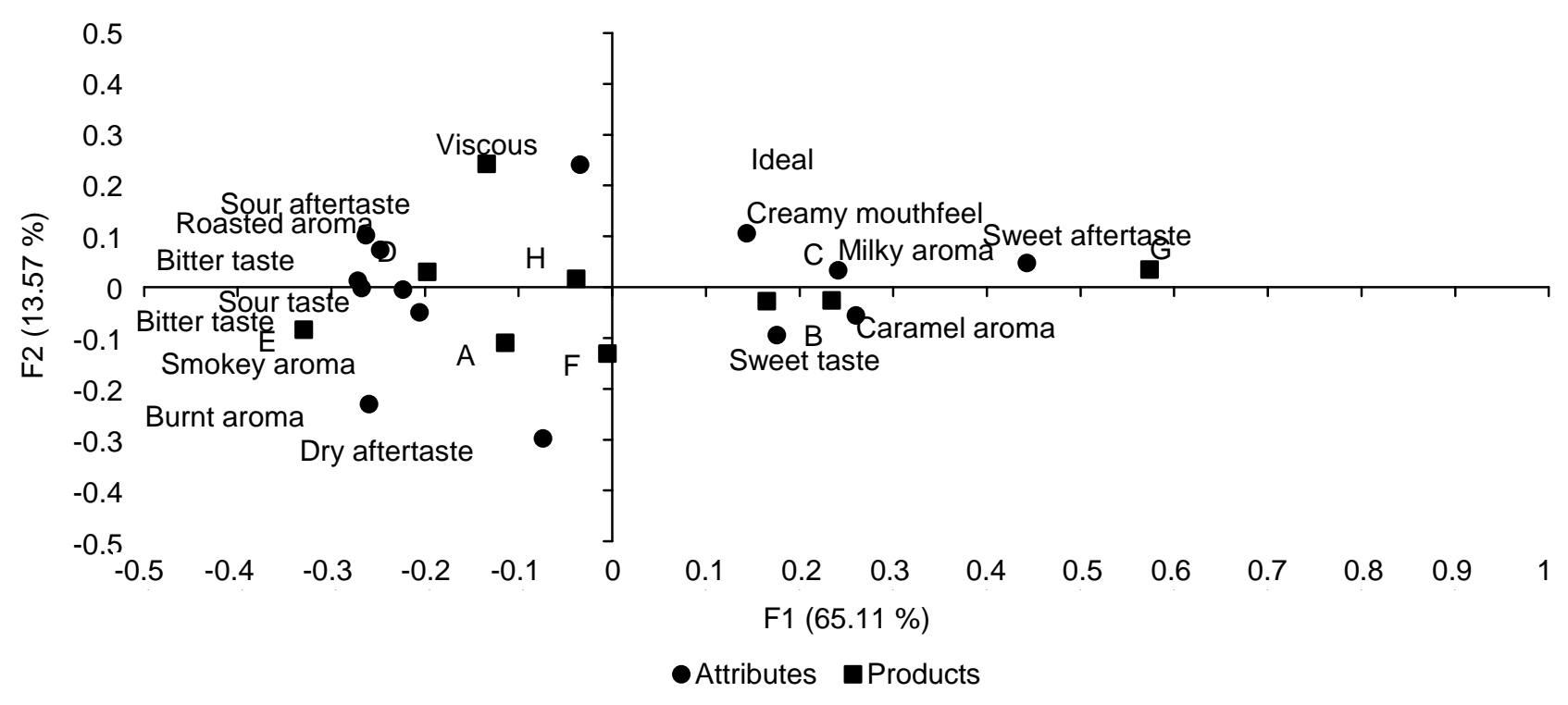

Figure 3. The sensory profile of 3 in 1 instant coffee and ideal coffee was represented using XLSTAT CATA Analysis - Coffee $\mathrm{C}$ is the most closely related product to the IDEAL Characteristics

Based on the results of the Correspondence analysis in Figure 4, it showed that the ideal sensory profile of coffee was coffee that has roasted aroma, creamy mouthfeel, milky taste and viscous. The sample closest to the criteria for ideal coffee was coffee $\mathrm{C}$ and coffee B. Coffee $\mathrm{C}$ has dominant attributes, namely creamy mouthfeel and milky aroma. Coffee $G$ has dominant attributes, namely sweetness aftertaste, while coffee $B$ has dominant attributes, namely caramel aroma and sweet taste. Meanwhile the sample farthest from the ideal coffee criteria is coffee $G$. Meanwhile, coffee $F$ has a dominant attribute, namely a dry aftertaste.

Based on the CATA Analysis results, there was Principal Coordinate Analysis ( $\mathrm{PCoA}$ ) graph that illustrates the correlation between sensory attributes and panelists' preferences for commercial coffee samples that have been tested. The PCoA analysis results in Figure 5 shows that the dominant attributes that affect the panelists' preferences are sweetness, smokey aroma.

Preference mapping is a technique that connects consumer acceptance data (hedonic data) with product sensory characteristics (descriptive data) to determine product characteristics that affect consumer preferences (Ferini et al., 2020; Gidlöf et al., 2021). The part that is also included in preference mapping is the contour plot, whose function is to show the number of clusters with a preference level above average. The level of preference for each cluster is expressed in percent (\%), and each color has a different percentage (Manik et al., 2016). The results of the preference mapping can be seen in Figure 5.

The preference mapping results showed that there was no red zone. It meaned that there was no single product that has high liking score above the average liking of the panelists for $80-100 \%$. The yellow area on the contour plot shows the panelists' preference percentage of $60-80 \%$ were coffee C, while in the light blue area there are $33 \%$ of panelists like cofee $A$, coffee $D$, coffe $E$, cofee $F$, and coffee B.

Panelists' attributes were sour taste, dry aftertaste, smokey aroma, sour aftertaste, viscous, creamy mouthfeel, sweet taste, caramel aroma, milky taste, and sweet aftertaste. The panelists' attributes were the watery mouthfeel, bitter aftertaste, bitter taste, burnt aroma, and aroma of roasting.

Penalty analysis identifies sensory attributes that can decrease or increase liking so that they can be used for product development. Penalty analysis on the CATA method can only be carried out if data on preferences and ideal product data were available. This analysis is divided into five groups of sensory attributes, namely must have, nice to have, does not influence, does not harm, and must not have (Khalafyan et al., 2021; Meyners et al., 2013), but only must-have, nice to have, and must not have. which will be analyzed because it has more influence on product development.

According to the panelists, the must-have attribute analysis was based on the mismatch of attributes that are not found in real products but ideal products. The attribute is based on the condition $\mathrm{P}(\mathrm{No}) \mid$ (Yes) and $\mathrm{P}$ (Yes) | (Yes). P (No) | (Yes) is a condition where a sensory attribute is not found in the sample product but is desired in the ideal product. In contrast, $\mathrm{P}$ (Yes) | (Yes) is a condition in which these sensory attributes are present in both the sample product and the ideal product (Meyners et al., 2013). 


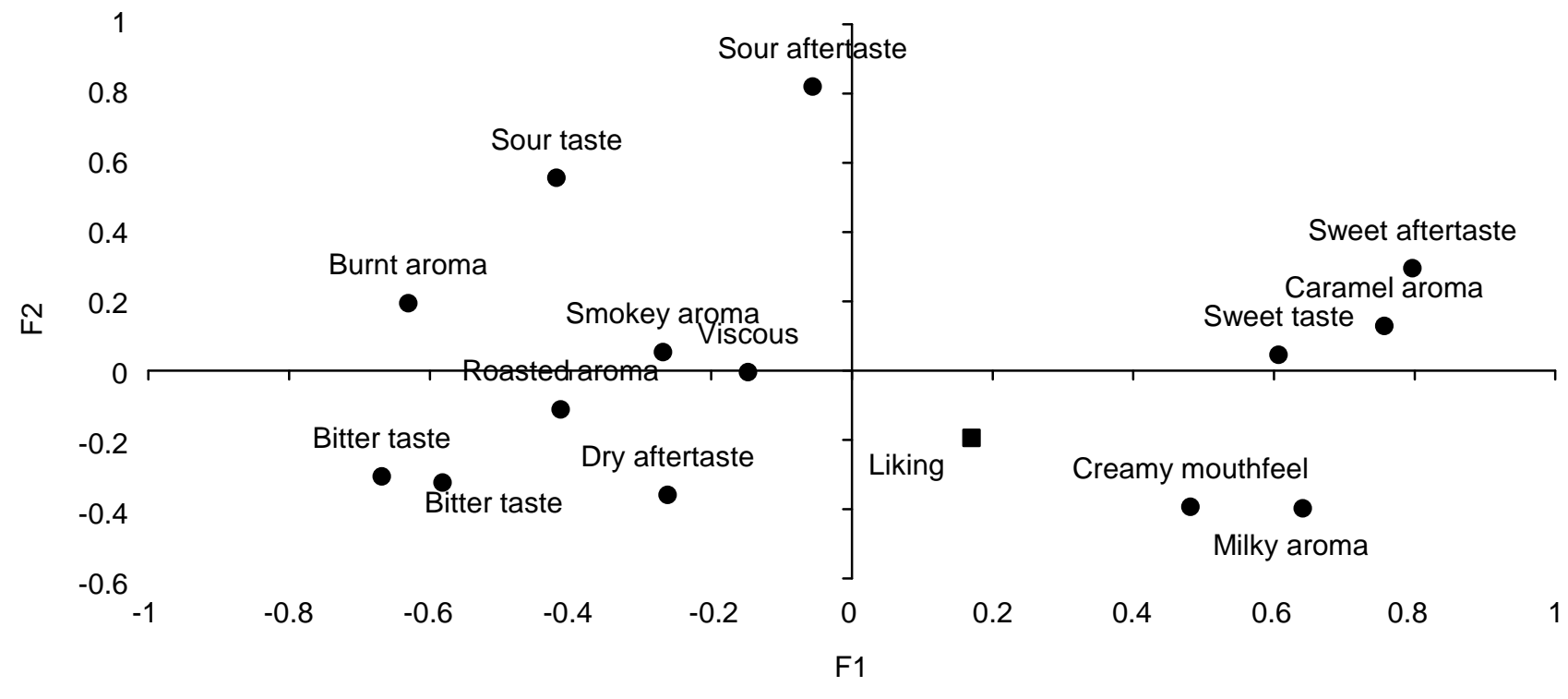

Figure 4. The correlation between the attributes and preferences of commercial 3-in-1 coffees demonstrates the attributes that contribute to liking

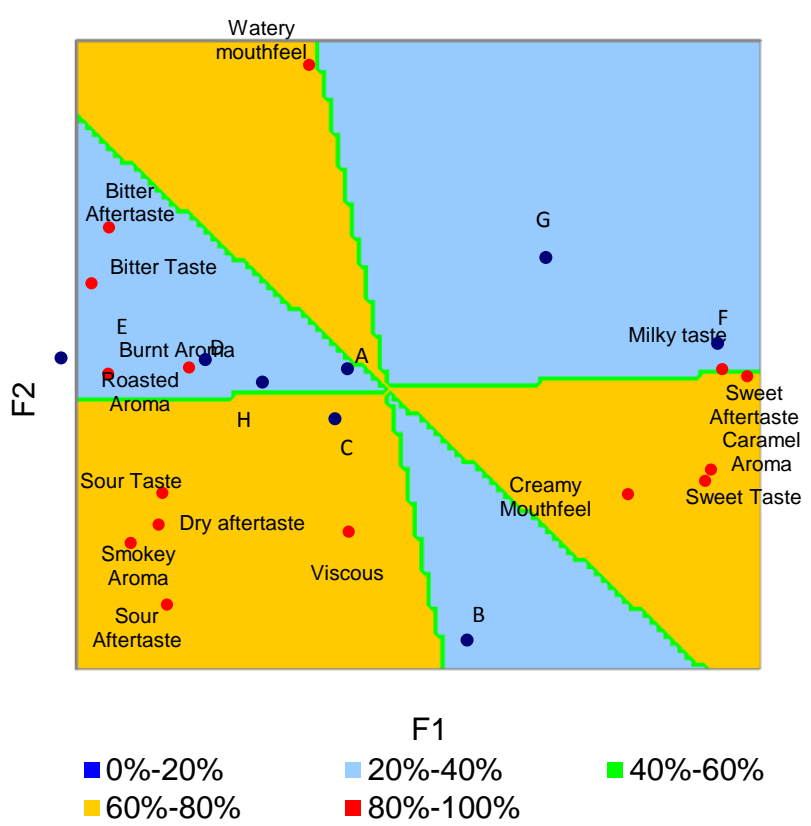

Figure 5. Preference mapping for 3-in-1 instant coffee samples among panelists

The higher the $X$ coordinate value (\% $P(\mathrm{No})$ (Yes)) and $Y$ (mean drops) or the position of the sensory attributes, the more they are above the right of the graph, the better the sensory attribute is to have (must have).

The must-have attribute can be determined from the mean drops value and the condition $\mathrm{P}(\mathrm{No})$ I (Yes). The attributes that have the condition P (No) | (Yes), which is more than $20 \%$, are attributes in the form of roasted aroma (42\%), milky taste (24\%), bitter taste $(35 \%)$, bitter aftertaste $(33 \%)$, sweet aftertaste $(21 \%)$, creamy mouthfeel $(40 \%)$, and Viscous (40\%). Figure 6 shows that the attributes that have a positive mean drop value include milky taste (0.575), creamy mouthfeel $(0.396)$, sweet aftertaste (0.099), bitter taste (0.152), bitter aftertaste (0.074), roasted aroma (0.183), and Viscous $(0.015)$. The significant positive mean drops in the attributes of milky taste (0.575) and mouthfeel creamy (0.396) cause milky taste and creamy mouthfeel to have the potential to be a must-have attribute and significant at the $5 \%$ test level.

The must not have attributes are the opposite of the must have attribute, namely the suitability of the attributes found in real products but not in ideal products according to panelists (Meyners et al., 2013). The difference between the nice to have and must not have attributes is that the nice to have attribute increases the panelists' liking, while the must not have attribute decreases the panelists' liking (Rocha et al., 2021). A sensory attribute has the potential to become a nice to have attribute if the mean value drops is positive, while if the mean drop value is negative it is categorized as a must not have attribute.

The attributes that have the condition $\mathrm{P}$ (Yes) | (No) which is more than $20 \%$ are attributes in the form of caramel aroma (22\%), sweet taste (25\%), dry aftertaste $(25 \%)$, and mouthfeel watery $(39 \%)$. As illustrated in Figure 7, positive mean drop values are associated with caramel aroma (0.004) and dry aftertaste (0.028), whereas negative mean drop values are associated with mouthfeel watery $(-0.404)$ and sweetness (-0.014). 


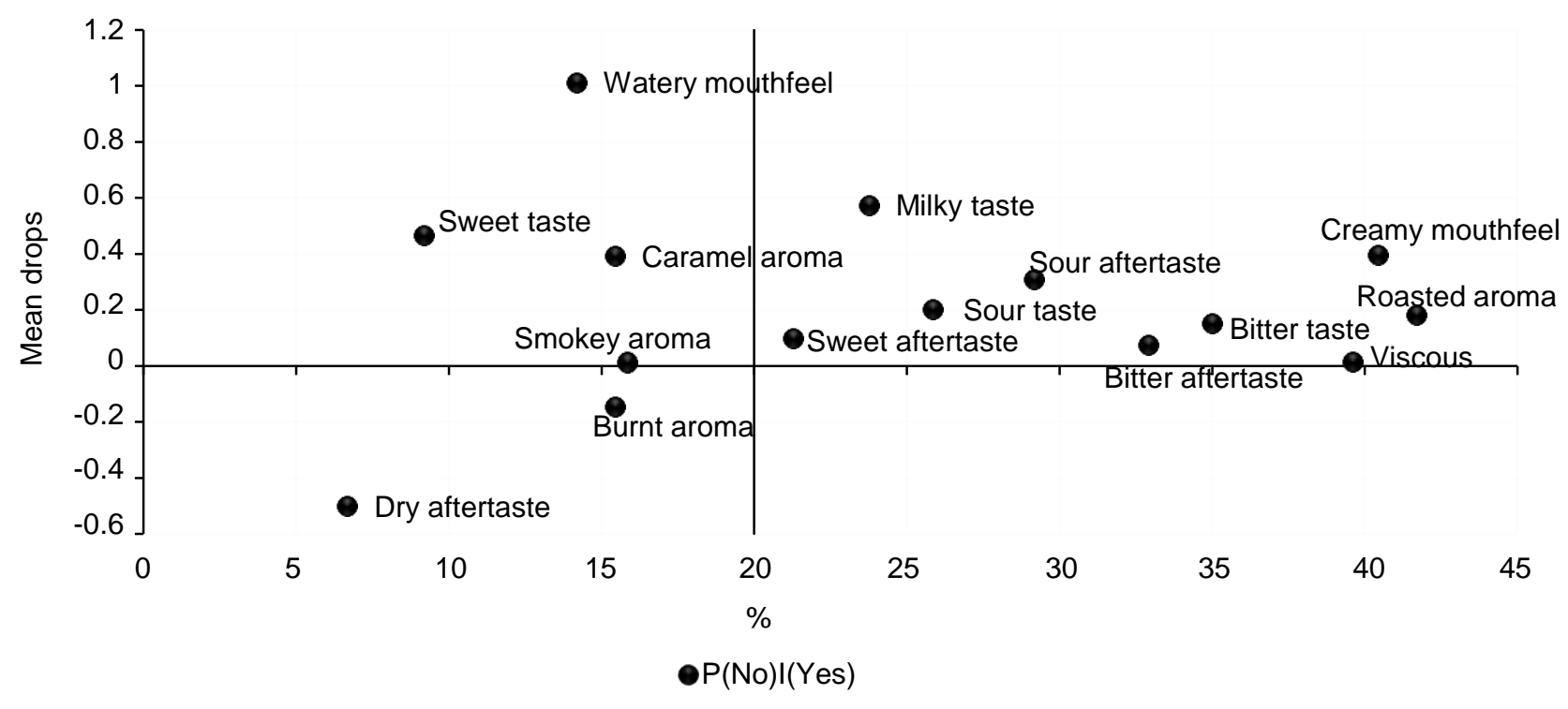

Figure 6. Penalty analysis of the must-have characteristics of commercial 3 -in-1 coffees was conducted

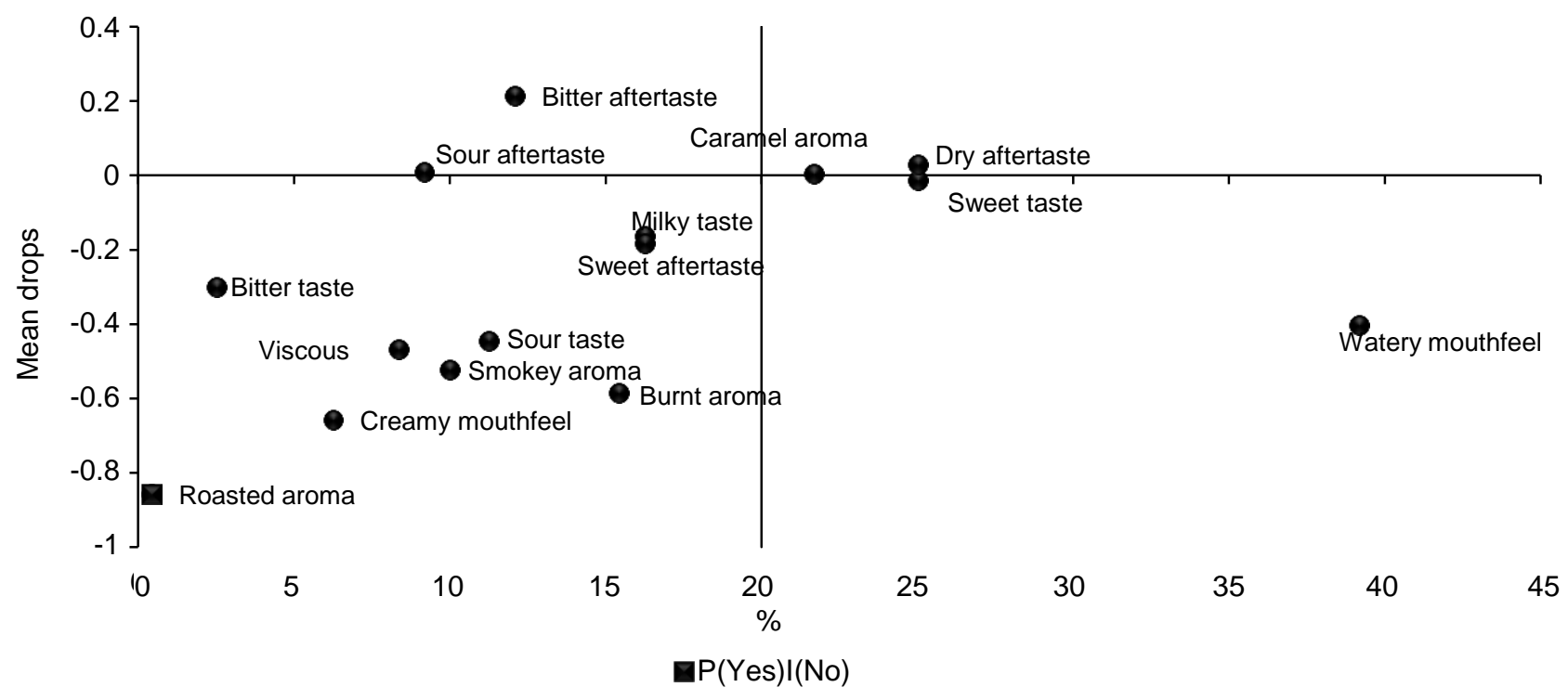

Figure 7. Penalty analysis of the nice to have and must not have attributes of commercial 3 -in- 1 coffees

The significant negative mean drop value ($0.404)$ for the mouthfeel watery attribute results in mouthfeel watery potentially becoming a must not have attribute at the $5 \%$ test level. The results of the nice to have attribute ana-lysis show that there are no attributes that fall into the nice to have category. This is because the mean value of positive drops is very low (close to 0.000) so it can be ignored (Córdoba et al., 2021).

The summary results of penalty analysis in Table 3 show that the sensory attributes that fall into the must have category are milky taste and creamy mouthfeel. Sensory attributes that fall into the does not influence category are roast aroma, bitter taste, bitter aftertaste, and Viscous. Sensories that fall into the does not harm category are smokey aroma, burnt aroma, sour taste, sour aftertaste, dry aftertaste, and sweet aftertaste, mouthfeel watery sensory attributes the must not have the category. No sensory attributes fall into the category nice to have.

\section{3 in 1 instant coffee emotion profile}

Cochran's $Q$ test shows that all emotional attributes are not significantly different in each sample at the $5 \%$ significance level, except for happy emotions $(P=0.034)$. A biplot map that illustrates the correlation between the sample and the emotional attributes tested can be seen in Figure 8 . 
Table 3. Penalty analysis summary

\begin{tabular}{|c|c|c|c|c|}
\hline Must Have & Nice to Have & Does not Influence & Does not Harm & Must not Have \\
\hline $\begin{array}{c}\text { Milky taste } \\
\text { Creamy mouthfeel }\end{array}$ & & $\begin{array}{l}\text { Roasted aroma } \\
\text { Bitter taste } \\
\text { Aftertaste pahit } \\
\text { Viscous }\end{array}$ & $\begin{array}{c}\text { Smokey aroma } \\
\text { Burnt aroma } \\
\text { Sour taste } \\
\text { Sour aftertaste } \\
\text { Dry aftertaste } \\
\text { Sweet aftertaste }\end{array}$ & Watery mouthfeel \\
\hline
\end{tabular}

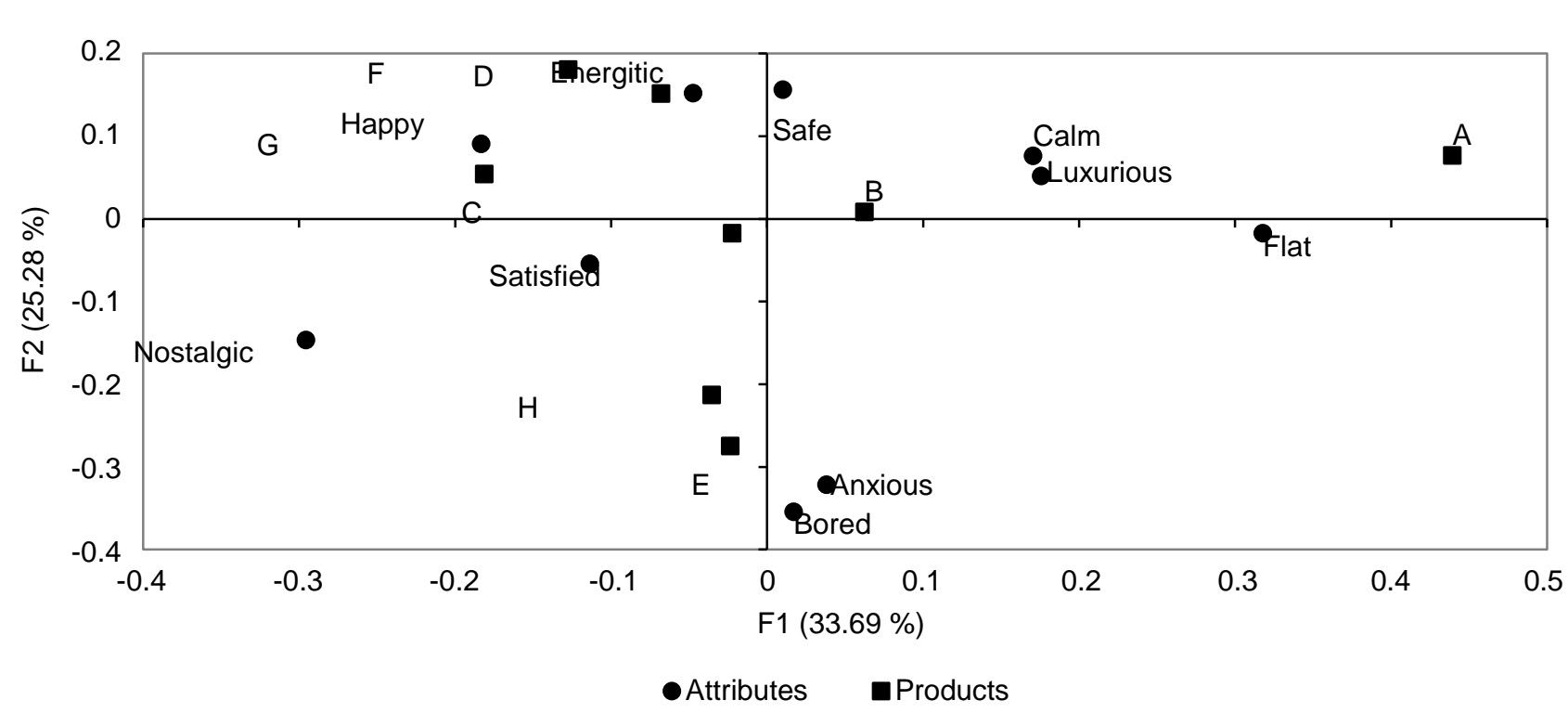

Figure 8. Representation of the emotional profile of commercial 3 in 1 instant coffees

According to the Correspondence analysis results in Figure 8 , consumers experience happy and energetic emotions when tasting coffee $D$. The emotions evoked by tasting coffee $\mathrm{G}$ are positive. In comparison, the emotions evoked by the taste of coffee $\mathrm{F}$ are energizing. When tasting coffee $\mathrm{B}$, one feels secure, calm, and luxurious, whereas when tasting coffee $\mathrm{A}$, one feels flat. When tasting coffee $\mathrm{C}$, the emotions were satisfied and happy, whereas when tasting coffee $E$, the emotions were bored and anxious.

The association between sensory profiles and emotions reveals that several sensory profiles are identical between the flash profile and CATA methods, specifically milky attributes on coffee $C$, bitter attributes on coffee $\mathrm{E}$, and sweet attributes on original coffee B. Table 4 demonstrates that sensory attributes have an effect on the emotions experienced when tasting a product. Positive emotions can be evoked by sensory attributes with a sweet aroma and taste, whereas bitter aromas and tastes are more effective at eliciting negative emotions. Positive emotional characteristics such as happiness, vitality, satisfaction, security, calmness, and opulence are influenced by sensory characteristics such as sweetness, sweet aftertaste, milky taste, caramel aroma, creamy mouthfeel, and roasted aroma. In comparison, negative emotional charac- teristics such as boredom and anxiety are influenced by the bitter aftertaste and burnt aroma.

\section{CONCLUSION}

The application of relatively new methods in the sensory evaluations of 3 in 1 instant coffee, Emotional-Sensory Mapping, Flash Profile, and CATA (Check-All-That-Apply) methods, resulted in a better understanding of the overall concept of sensory profiling, which the food industry can use to locate the targeted sensory space, including the emotions elicited by the product sensory attributes. Three samples of 3 in 1 instant coffee, namely coffee C, coffee $E$, and coffee $B$ have the same sensory attributes in the flash profile and CATA methods. According to the panelists in around IPB Darmaga Campus, the most preferred product and approaching ideal coffee was coffee $C$ with sensory attributes in the form of milky taste, creamy mouthfeel, roasted aroma, and viscous and resulted in satisfied and happy emotional attributes. Employing wider consumers area is advisable. Revalidating attributes selected in the first FGD with data collected in the second FGD is recommended. 
Tabel 4. Correlation summary 3 in 1 instant coffee

\begin{tabular}{|c|c|c|c|}
\hline \multirow{2}{*}{ Sample } & \multicolumn{3}{|c|}{ Dominance Attributes Sensory Profiling } \\
\hline & Flash Profile & CATA & Emotional Sensory Mapping \\
\hline$A$ & Caramel aroma & $\begin{array}{l}\text { Smokey aroma } \\
\text { Burnt aroma }\end{array}$ & Flat \\
\hline B & $\begin{array}{l}\text { Milky taste } \\
\text { Sweet taste }\end{array}$ & $\begin{array}{l}\text { Caramel aroma } \\
\text { Sweet taste }\end{array}$ & $\begin{array}{c}\text { Safe } \\
\text { Calm } \\
\text { Luxurious }\end{array}$ \\
\hline $\mathrm{C}$ & $\begin{array}{l}\text { Milky taste } \\
\text { Sweet taste }\end{array}$ & $\begin{array}{l}\text { Creamy mouthfeel } \\
\text { Milky taste }\end{array}$ & Satisfied \\
\hline $\mathrm{D}$ & Caramel aroma & $\begin{array}{l}\text { Smokey aroma } \\
\text { Sour taste }\end{array}$ & $\begin{array}{l}\text { Happy } \\
\text { Energetic }\end{array}$ \\
\hline $\mathrm{E}$ & $\begin{array}{c}\text { Bitter taste } \\
\text { Coffee id } \\
\text { Sour taste } \\
\text { Nutty aroma }\end{array}$ & $\begin{array}{l}\text { Bitter aftertaste } \\
\text { Burnt aroma }\end{array}$ & $\begin{array}{l}\text { Bored } \\
\text { Anxious }\end{array}$ \\
\hline $\begin{array}{l}F \\
G \\
H\end{array}$ & $\begin{array}{l}\text { Creamy Mouthfeel } \\
\text { Creamy mouthfeel } \\
\text { Creamy mouthfeel }\end{array}$ & $\begin{array}{c}\text { Sweet taste } \\
\text { Sweet aftertaste } \\
\text { Roasted aroma } \\
\text { Sour aftertaste } \\
\text { Viscous }\end{array}$ & $\begin{array}{l}\text { Energetic } \\
\text { Happy } \\
\text { Satisfied }\end{array}$ \\
\hline
\end{tabular}

\section{REFERENCES}

Ares G, Dauber C, Fernández E, Giménez A, Varela P. 2014. Penalty analysis based on CATA questions to identify drivers of liking and directions for product reformulation. Food Qual Prefer 32A: 65-76. DOI: 10.1016/j.foodqual. 2013.05.014.

Belusso AC, Nogueira BA, Breda LS, Mitterer-Daltoé ML. 2016. Check-all-that-apply (CATA) as an instrument for development of fish products. Food Sci Technol 36: 275-281. DOI: 10.1590/ 1678-457X.0026.

Bemfeito CM, Guimarães AS, de Oliveira $A L$, Andrade BF, de Paula LMAF, Pimenta CJ. 2021. Do consumers perceive sensory differences by knowing information about coffee quality?. LWT-Food Sci Technol 138: 110778. DOI: 10.1016/j.Iwt.2020.110778.

Berget I, Bech S, Giacalone D, Moulin S, Pedersen ME, Varela P. Næs T. 2020. Sound quality perception of loudspeakers evaluated by different sensory descriptive methods and preference mapping. J Sens Stud: e12620. DOI: 10.1111/ joss.12620.

Córdoba N, Moreno FL, Osorio C, Velásquez S, Ruiz Y. 2021. Chemical and sensory evaluation of cold brew coffees using different roasting profiles and brewing methods. Food Res Int 141: 110141. DOI: 10.1016/j.foodres.2021.1101 41.

de Melo BG, de Lima Dutra MB, Alencar NMM. 2021. Sensory characterization of conventional and organic extra virgin olive oil by check-all- that-apply and emotional responses methods. $\mathrm{J}$ Sens Stud 36: e12641. DOI: 10.1111/joss.126 41.

Gao C, Tello E, Peterson DG. 2021. Identification of coffee compounds that suppress bitterness of brew. Food Chem 350: 129225. DOI: 10.1016/j. foodchem.2021.129225

Ferini JL, Morales MV, da Silva TA, Pedreira JRM, de Godoy NT, de Oliveira Garcia A, Tfouni SAV. 2020. Consumers' perception of different brewed coffeeextractions using the sorting technique. J Sens Stud 2020: e12633. DOI: 10. 1111 /joss.12633

Fujimoto H, Narita Y, Iwai K, Hanzawa T, Kobayashi T, Kakiuchi M, Ariki S, Wu X, Miyake K, Tahara Y, Ikezaki H, Fukunaga T, Toko K. 2021. Bitterness compounds in coffee brew measured by analytical instruments and taste sensing system. Food Chem 342: 28228. DOI: 10.1016/ j.foodchem.2020.128228.

Grasso S, Monahan FJ, Hutchings SC, Brunton NP. 2016. The effect of health claim information disclosure on the sensory characteristics of plant sterol-enriched turkey as assessed using the Check-All-That-Apply (CATA) methodology. Food Qual Prefer 57: 69-78. DOI: 10.1016/j. foodqual.2016.11.013.

Gidlöf K, Ares G, Aschemann-Witzel J, Otterbring T. 2021. Give us today our daily bread: The effect of hunger on consumers' visual attention towards bread and the role of time orientation. Food Qual Prefer 88: 1-7. DOI: 10.1016/j.food qual.2020.104079. 
Hirschmann. 2020. Coffee market in Indonesiastatistics \& facts. https://www.statista.com/to pics/6546/coffee-market-in-indonesia/ [January $\left.29^{\text {th }} 2021\right]$.

Hirschmann. 2021. Total coffee consumption in Indonesia 1990-2019. https://www.statista.com/ statistics/314982/indonesia-total-coffee-consum ption/\#: :text=Indonesia\%27s\%20domestic\%20 coffee\%20consumption\%20has,appreciation\%2 Ofor\%20locally\%2Dproduced\%20coffee [January $29^{\text {th }} 2021$ ]

Huang J, Wang C, Wan X. 2021. Self-construal priming modulates the influence of receptacles onfood perception. J Sens Stud 36: e12642. DOI: $10.1111 /$ joss.12642.

Huseynov S, Palma MA. 2021. Food decisionmaking under time pressure. Food Qual Prefer 88: 104072. DOI: 10.1016/j.foodqual.2020.1040 72.

[ICO] International Coffee Organization. 2021. Monthly Coffee Market Report-January 2021. http:// www.ico.org/documents/cy2020-21/cmr-0121-e. pdf [January $10^{\text {th }} 2021$ ].

Jaeger SR, Lee P-Y, Xia Y, Chheang SL, Roigard CM, Ares G. 2019. Using the emotion circumplex to uncover sensory drivers of emotional associations to products: six case studies. Food Qual Prefer 77: 89-101. DOI: 10.1016/j.food qual.2019.04.009.

Keskin S, Kor A, Karaca S. 2012. Evaluation of sensory characteristics of sheep and goat meat by Procrustes analysis. Czech J Anim Sci 57: 516-521. DOI: 10.17221/6384-CJAS.

Khalafyan AA, Temerdashev ZA, Akin'shina VA, Yakuba YF. 2021. Study of consistency of expert evaluations of wine sensory characteristics by positional analysis. Heliyon 7: e06162. DOI: 10.1016/j.heliyon.2021.e06162.

Labbe D, Rytz A, Strube A, Leloup V. 2021. Impact of mug shape and beverage volume on instant coffee perception. Food Qual Prefer 89: 1-5. DOI: 10.1016/j.foodqual.2020.104150.

Lobo AP, Bedriñana RP, Madrera RR, Valles BS, 2021. Aromatic, olfactometric and consumer description of sweet ciders obtained by cryoextraction. Food Chem 338: 1-8. DOI: 10.1016/ j.foodchem.2020.127829

Mané I, Bassama J, Ndong M, Mestres C, Diedhiou PM, Fliedel G. 2021. Deciphering urban consumer requirements for rice quality gives insights for driving the future acceptability of local rice in Africa: Case study in the city of Saint-Louis in senegal. Food Sci Nutr 9: 1614-1624. DOI: 10. 1002/fsn3.2136.

Manik M, Restuhadi F, Rossi E. 2016. Analisis pemetaan kesukaan konsumen terhadap lempuk dikalangan mahasiswa Universitas Riau. Jom Faperta 3: 1-15.

Manstan T, Chandler SL, McSweeney MB. 2020. Consumers' attitudes towards 3D printedfoods after a positive experience: An exploratory study. J Sens Stud 36: e12619. DOI: 10.1111/j oss.12619.

McCain-Keefer HR, Meals S, Drake MA. 2020. The sensory properties and consumer acceptance of cold brew coffee. J Sens Stud 35: e12604. DOI: $10.1111 /$ joss.12604.

Meyners M, Castura JC, Carr BT. 2013. Existing and new approaches for the analysis of CATA data. Food Qual Prefer 30: 309-319. DOI: 10.1016/j. foodqual.2013.06.010.

Montanuci FD, Marques DR, Monteiro ARG. 2015. Flash profile for rapid descriptive analysis in sensory characterization of passion fruit juice. Maringá 37: 337-344. DOI: 10.4025/actascitech nol.v37i3.26238.

Nasermoadeli A, Ling KC, Maghnati F. 2012. Evaluating the impacts of customer experience on purchase intention. Int J Bus Manag 8: 128138. DOI: 10.5539/ijbm.v8n6p128.

Nezlek JB, Forestell CA, Cypryanska M. 2021. Approach and avoidance motivation and interest in new foods: Introducing a measure of the motivation to eat new foods. Food Qual Prefer 88: 104111. DOI: 10.1016/j.foodqual. 2020.104111.

Pramudya RC, Singh A, Seo H-S. 2021. A sip of joy: Straw materials can influence emotional responses to, and sensory attributes of cold tea. Food Qual Prefer 88: 104090. DOI: 10.1016/j. foodqual.2020.104090.

Ribeiro E, de Souza Rocha T, Prudencio SH. 2021. Potential of green and roasted coffee beans and spent coffee grounds to provide bioactive peptides. Food Chem 348: 129061. DOI: 10.10 16/j.foodchem.2021.129061.

Rabelo MHS, Borém FM, de Lima RR, de Carvalho Alves AP, Pinheiro ACM, Ribeiro DE, dos Santos, Gualberto R, Pereira RGFA. 2021. Impacts of quaker beans over sensory characteristics and volatile composition of specialty natural coffees. Food Chem 342: 128304. DOI: 10.1016/j.foodchem.2020.128304. 
Reinbach HC, Giacalone D, Ribeiro LM, Bredie WLP, Frøst MB. 2014. Comparison of three sensory profiling methods based on consumer perception: CATA, CATA with intensity and Napping®. Food Qual Prefer 32: 160-166. DOI: 10.1016/j.foodqual.2013.02.004.

Rocha C, Ribeiro JC, Lima RC, Prista C, Raymundo A, Patto MCV, Cunha LM. 2021. Application of the CATA methodology with children: Qualitative approach on ballot development and product characterization of innovative products. Food Qual Prefer 88: 104083. DOI: 10.1016/j. foodqual.2020.104083.

Valentin D, Chollet S, Lelièvre M, Abdi H 2012. Quick and dirty but still pretty good: a review of new descriptive methods in food science. Int $\mathrm{J}$ Food Sci Technol 47: 1563-1578. DOI: 10.111 1/j.1365-2621.2012.03022.x.
Varela P, Ares G. 2012. Sensory profiling, the blurred line between sensory and consumer science. A review of novel methods for product characterization. Food Res Int 48: 893-908. DOI: 10.1016/j.foodres.2012.06.037.

Veríssimo CM, de Macêdo Morais S, de Andrade Lima LL, Pereira GE, Maciel MIS. 2020. A short training as an enhancer of sensory ability: The case of red wine consumers. J Sens Stud 36: e12629. DOI: 10.1111/joss.12629.

Yusianto, Nugroho D. 2014. Mutu fisik dan citarasa kopi arabika yang disimpan buahnya sebelum di-pulping. Pelita Perkebunan 30: 137-158. DOI: 10.22302/iccri.jur.pelitaperkebunan.v30i2.7.

Zanin RC, Smrke S, Kurozawa LE, Yamashita F, Yeretzian C. 2021. Modulation of aroma release of instant coffees through microparticles of roasted coffee oil. Food Chem 341: 128193. DOI: 10.1016/j.foodchem.2020.128193. 